\title{
CONFLICTS OF JURISDICTION IN CRIMINAL PROCEEDINGS - PRECONDITIONS AND POSSIBLE SOLUTIONS
}

\author{
Ralitsa VOYNOVA \\ "Neofit Rilski" South-West University, Blagoevgrad, Bulgaria \\ rmv77@law.swu.bg
}

\begin{abstract}
The article examines issues, related to the conflicts of jurisdiction in criminal proceedings within the European area, where several countries simultaneously have the competence to conduct a criminal prosecution of the same facts. There have been studied several international legal instruments, postulating the compliance with the Ne bis in idem principle, respectively the prohibition of a second judgment towards the same person and for the same act. Discussed are various preconditions for conflicts of jurisdiction in criminal matters and possible solutions, according to the existing legal mechanisms in this field.
\end{abstract}

Keywords: jurisdiction, conflict, cross-border crimes, transfer, Ne bis in idem principle

\section{Introduction}

The removal of borders within the European area, after adoption of the Schengen Agreement [1], facilitates the free movement of persons, services and goods. However, these positive globalization processes led to some negative phenomena, such as the appearance of organized criminal groups and increased transnational criminality. The crimes with an international element are acts that threaten and violate both the national and the International law, and therefore they are characterized by extremely high level of public danger.

The necessity of appropriate mechanisms for countering criminality, going beyond national borders, laid the foundations for the development of an international criminal justice and transnational criminal justice. [2] In the theory, cross-border crimes are seen as a subject matter to the domestic criminal law with an international element. "Unlike international crimes, characterized by a global scale, due to their orientation against the peace and security of humanity (genocide, wars of aggression and serious acts of terrorism), the transnational crimes are deeds, which beginning of performance, time of completion, results and perpetrators are linked to more than one country." [3]

In this sense, several countries, in which crimes or part of them are committed, are potentially interested in prosecuting criminal acts that affect their national security or other rights, protected by their national law. The Ne bis in idem principle has to comply with the mandatory prosecution principle, which is an expression of the sovereignty and which the countries could hardly give up.

\section{Preconditions for conflicts of} jurisdiction in criminal proceedings

European practice in the criminal justice certifies that countries often face with situations, in which two or more of them have the competence to initiate criminal proceedings for the same or related crimes. 
In some cases, the criminal jurisdiction of the country is based on the principle of territoriality, e.g. when the crime is committed on its territory or, even if committed abroad, the harmful consequences have occurred in its territory. A duplication of jurisdiction may also occur in cases, where the offense is committed on the territory of several countries. These are the so-called "cross-border crimes", such as human trafficking [4]; smuggling; money laundering; trafficking and distribution of drugs, etc. Of the same kind are the crimes, where the negative consequences have occurred in two or more countries, e.g. cyber-attacks, the use of nuclear, chemical or biological weapons.

In other cases, the country is competent to apply its criminal law based on personal principle, e.g. when the crime is committed by a national or by a permanent resident in its territory. Conflicts of jurisdiction are possible also in cases of dual nationality of the alleged offender.

There are also cases, where a country has jurisdiction to prosecute according to the universal principle, e.g. when the crime violates the peace and humanity, which are globally shared values.

Thus, the countries' criminal jurisdiction is based on different legal principles of applicability of their national criminal law. The right of every sovereign country to administer justice, in accordance with its national legislation, is limited by the obligation to respect and apply the international principles and legal rules in the criminal justice. Therefore, it is true that "Each right is placed into a system of legal obligations that determine the boundaries of its implementation in the legal reality. Their existence depends on the willingness of the right holder, of that of third parties and the state, and it is a consequence of their mutual respect." [5]

\section{International legal instruments addressing the issue of resolving conflicts of jurisdiction}

Since the national law of the most European Countries does not always grant a res iudicata effect to foreign judgments, the main purpose of the European Institutions was to approve a multilateral treaty, in order to avoid the risk of double jeopardy in criminal matters.

An explicit legal regulation of the principle of $\mathrm{Ne}$ bis in idem appeared first in Art.9 of the 1957 European Convention on Extradition, Art.53 of the 1970 Convention on the International Validity of Criminal Judgements and Art.35 of the 1972 European Convention on the Transfer of Proceedings in Criminal Matters.

Later on, the provisions of Title III, Chapter III of the European Convention on the Implementation of the Schengen Agreement of 14 June 1985 (CISA) [6] were entirely dedicated to the prohibition of a second judgment towards the same person and for the same act. According to Art.54 of CISA: "A person, whose trial has been finally disposed of in one Contracting Party, may not be prosecuted in another Contracting Party for the same acts provided that, if a penalty has been imposed, it has been enforced, is actually in the process of being enforced or can no longer be enforced under the laws of the sentencing Contracting Party."

The European Court of Justice in its preliminary ruling decisions ruled that Art.54 of CISA introduces as a corollary to the freedom of movement a "negative" meaning, i.e. that the right to move from one State to another should not have negative consequences, i.e. multiple prosecutions towards the same person for the same act. According to the independent interpretation of idem factum, given by the European Court of Justice: the only relevant aspects are material acts, understood in the sense of the existence of a set of concrete circumstances, which are inextricably linked together. However, the definitive assessment belongs to the competent national court, which has the jurisdiction to determine whether the material acts 
constitute a set of facts, linked together in time, in space and by their subject matter. The Court stated that the concept of "same acts" should not be different in each Member State. On the opposite, an autonomous and uniform interpretation within the European Union needs to be provided. [7] In its following decisions, the Court ruled that a lack of complete identity of the material facts does not prevent the effect of the $\mathrm{Ne}$ bis in idem principle.

In order to limit the effects of the growing international and cross-border criminality, the European legislator takes a series of improved measures towards the establishment of a single area of criminal justice, which is characterized by mutual trust and support among the national enforcement and judicial authorities. A fundamental factor in this direction is the introduction of the principle of mutual recognition of judgments, which is seen as a cornerstone of the judicial cooperation between EU Member States. [8] The successful implementation of this principle requires mutual trust between Member States, in particular - trust in their criminal justice systems. This level of confidence should be high enough to allow the refusal of the national court to apply its criminal law in favour of the law of another Member State. [9]

The entry into force of the Treaty on the Functioning of the European Union (TFEU) [10], and the removal of the pillar structure opens the path to a European Common criminal area. The latter combines on one hand - EU law in the field of criminal justice, on the other - the cooperation between countries in criminal matters, without prejudice to the national sovereignty of each of them. The competence in "the area of security, freedom and justice" becomes a shared competence. EU Member States have the possibility to apply their national jurisdictions in these areas, as far as the EU has not exercised its competence or has decided to provide its exercise. [11]
The processes of institutionalization and harmonization inevitably lead to some difficulties in law enforcement, which are mainly caused by differences in the various legal systems. So, in the theory is stated that: "in the EU legal system there is an extremely complicated combination of jurisdictions from three legal orders, such as international law, EU law and national law of the Member States." [12]

After the Tampere program and the subsequent Hague Program, the European Council endorses the new multiannual program for the area of freedom, security and justice for the period 2010-2014, i.e. the Stockholm program. Its key objective is to improve judicial cooperation in criminal matters within the European Union, focusing on expanding the activities of the European Judicial Network, Eurojust, Joint Investigation Teams, and the exchange of magistrates between European countries in countering the serious cross-border crimes. [13]

According to Art.82, §1, letter "b" of TFEU, the Union is competent in preventing and solving conflicts of jurisdiction among Member States. However, specific rules on prevention and resolution of conflicts of jurisdiction were lacking by that time.

A next step was taken with the 2005 Green Paper on Conflicts of jurisdiction and the Principle of $\mathrm{Ne}$ bis in idem in Criminal Proceedings, published by the European Commission. The Green Paper provides three stages: 1) exchange of information between competent authorities about pending criminal proceedings, 2) consultations among countries involved, 3) agreement in order to resolve the conflict of jurisdiction.

In comments to the Green Paper are stated opinions that the $\mathrm{Ne}$ bis in idem principle does not prevent conflicts of jurisdiction between countries, but it rather plays the role of "a safety net", in cases, where there are preconditions the same person to be punished twice for the same crime. [14] 
The consultations, opened on the Green Paper, result in the 2009/948/JHA Framework Decision on the prevention and settlement of conflicts of exercise of jurisdiction in criminal proceedings [15], that Member States were expected to implement before 15th June 2012. It should be noticed that regardless of its title, there are no rules on prevention of conflicts - it provides only rules, concerning resolution of conflicts. The Framework Decision introduces a complete procedure for mandatory exchange of information and direct consultations between competent authorities of EU Member States, aiming to prevent infringement of the principle of $\mathrm{Ne}$ bis in idem, referred to in the provision of Article 54 of CISA.

\section{Possible solutions for conflicts of jurisdiction in the conditions of multiple criminal proceedings}

There are various reasons why the conduct of criminal proceedings would be more successful in another country than in the country, where it was originally initiated. For example, when during the period of consideration of criminal proceedings in one country, the alleged offender resides on the territory of another country or he is a national of the second; when the first country experience difficulties in securing evidence on its territory, but lots of or most important evidence can be collected in the territory of another country; when in the other country against the alleged offender there is already a pending criminal prosecution for the same and/or for a different criminal offense; or the suspect is already serving a sentence of imprisonment there. [16]

One of the oldest mechanisms for international cooperation in criminal matters is the transfer of criminal proceedings, which primary legal framework is established by the European Convention on the Transfer of Proceedings in Criminal Matters of the Council of Europe. [17] Its essential characteristic is the reassignment of jurisdiction from one country to another, resp. the concentration of the criminal proceedings in a single country, which is able ensure the most favourable conditions for prosecution. Undoubtedly, its application is generally based on the mutual trust between countries, resp. in their criminal justice systems.

In its part IV "Multiple criminal proceedings" the 1972 Convention rules the "parallel criminal proceedings", which are also a subject of regulation in Framework Decision 2009/948/JHA. Thus, according to Art.30, Para.1 of the 1972 Convention: "Each Contracting State, which before initiating or during the proceedings for an offense for which it considers that the is not of a political or a military nature, becomes aware for the proceedings pending in another Contracting State against the same person for the same offense, shall consider whether to terminate or temporarily suspend its proceedings, or transfer it to another country." The envisioned consultation procedure helps the countries to find a common acceptable solution in the so-called "positive conflict of jurisdictions", i.e. when two or more of them have the competence to conduct criminal proceedings for the same facts. If the interested parties manage to reach a consensus, they must transfer the results of the criminal prosecution, conducted by their competent authorities and gather them in one single criminal proceeding. Thus, the prosecution of the crime is entrusted to the country, which based on the factual circumstances of the case, could guarantee the most successful completion of the proceedings.

Obviously, the 1972 Convention and Framework Decision 2009/948/JHA have an identical objective, which they achieve through a similar procedure of direct consultation between the interested parties. It should be noticed that, as an EU instrument the Framework Decision 2009/948/JHA binds only the Member 
States of the Union, which have adopted it. On the other hand, only the countries, including those outside the Council of Europe, that have ratified it, are required by the provisions of the 1972 Convention.

Unlike the 1972 Convention though, the Framework Decision 2009/948/JHA does not contain an explicit rule, requiring the preparation of a formal request for transfer of the gathered evidence to the accepting country. The transfer of the results from the pending criminal proceedings is a logical consequence of the consultation procedure, following which the parties concerned have agreed the prosecution of the criminal case to be concentrated on the territory of one country. [18]

There is no doubt that both considered international instrument regulate different legal procedures, but it is also clear that under certain conditions these procedures lead to the same legal result, namely the transfer of criminal proceedings. Regardless of the semantic distinction between the used terms "transfer" and "concentration" in both regulations, the same does not justify a difference in the result sought. The legal consequences of both procedural activities lead to a "transfer of criminal jurisdiction" of one or more countries in favour of another.

Furthermore, if the Contracting Parties fail to reach a mutually acceptable solution for concentrating the prosecution of the crime in one country, under the provision of Article 12(2) of Framework Decision 2009/948/JHA, each of them may refer the matter to Eurojust. [19]

In accordance with the Article 13 (7) of Council Decision 2009/426/JHA of 16 December 2008 on the strengthening of Eurojust, Member States are required to inform Eurojust about any case of conflict of jurisdiction or the possibility of such a dispute. However, the role of Eurojust is limited in scope to the cases, in which it is competent to act. Eurojust is entitled to give its help, only when Member States voluntarily refer their dispute to it, if they cannot resolve it on their own and if it is appropriate, taking into account the subject matter.

Under the provisions of Article 7 (2) of the EU Council Decision 2009/426/JHA, Eurojust as a collegial body, may give written opinions about the method for resolving the conflicts of competence between EU Member States, but these opinions do not have binding effect. They serve only as recommendations and their execution depends on the free will of the countries. The Eurojust' request, expressed in its opinion on the Green Paper, that the Member States should be obliged to seek its arbitration, if they cannot reach consensus about the criminal jurisdiction, is rejected. The argument for this rejection was that it is better for Eurojust not to possess simultaneously the authority of a mediator and a decision-making body, where such a delicate matter is concerned.

\section{Conclusion}

It should be recognized that a lot of work has been accomplished in order to ensure the compliance with the principle of $\mathrm{Ne}$ bis in idem within the European area. Nevertheless, further steps in direction to more effective solutions between countries, conducting parallel criminal proceedings for the same fact and against the same person, are needed. This could be achieved by a new European law on prevention of conflicts of jurisdiction in criminal matters.

\section{References}

[1] Signed on 14 June 1985 in Schengen, Luxembourg.Its full implementation starts from July 1995 with the abolition of border controls between six of the signatory countries. Later on, it covers other European countries, including not members of EU.

[2] Pakes, Fr. Comparative Criminal Justice, Devon, Willan Publishing, 2004, pp. 141-168. 
[3] Салкова, Е. Прекратяване на наказателното производство, С. Фенея, 2007, с. 93. [4]Chankova, D. Combating Trafficking in Human Beings in Bulgaria: Achievements, Problems, Perspectives, Victimological Advances in Theory, Policy and Services, ed. by Tod Tollefson, 2015, pp. 27-37.

[5] Stanin, M. Rights within Obligations and Responsibilities, in: scientific collection "Economic, social and administrative approachesto the knowledge-based organization", Volume II, Land Forces Academy "Nicolae Balchesku", Sibiu, Romania, 2016, p.150.

[6] OJ L 239, 22.9.2000, pp.19-62.

[7] See ECJ decision of 16 November 2010, C-261/09, Gaetano Mantello; ECJ decision of 22 December 2008, C-491/07, Vladimir Turanský; ECJ decision of 28 September 2006, C-467/04, Giuseppe Francesco Gasparini and Others.

[8] The principle of mutual recognition of judgments was adopted by the Tampere European Council in October 1999 as a part of measures to improve the cooperation between MemberStates in the field of criminal justice.

[9] Suominen, A. The principle of mutual recognition in cooperation in criminal matters. Astudy of the principle in four framework decisions and in the implementation legislation in the Nordic Member States. Bergen, 2010.

[10] Signed on 13.12.2007in Lisbon, entered into force on 01.12.2009.

[11] Белова-Ганева, Г. По вопросу о верховенстве европейского права, Научный вестникДипломатической академии, Выпуск 18, Украины, Киев, 2012, с. 115-119.

[12] Марин, Н. Юрисдикичия на Съда на Европейския съюз в пространството на свобода, сигурност и правосъдие, УИ „Н. Рилски“, Благоевград, 2011 г., с.168-169.

[13] Savona, E. Trends and Causes of Cross-Border (Organized) Crime in Europe, in: Criminal Justice Co-operation in the European Union after Tampere, Series of publications by the Academy of European Law in Trier/ERA/, Vol. 33, 2002.

[14] Fischer, Juliette. Comments on the Green Paper on Conflicts of Jurisdiction and the principle of $\mathrm{Ne}$ bis in idem in criminal proceedings, The Max Planck Institute for Foreign and International Criminal Law, 2006, p.5.

[15] Signed in Brusselson 30.11.2009, OJ L 328, 15.12.2009.

[16] Bassiouni, M.Cherif. IntroductiontoInternationalCriminal Law, Secondrevisededition, Leiden;Boston: Martinus Nijhoff Publishers, 2013, pp. 510-512.

[17] Signed in Strasbourg on 05.15.1972

[18] Peers, Steve. "The proposed Framework Decision on conflict of jurisdiction incriminal proceedings:Manipulating the right to a fair trial?", in:Statewatch Analysis, 2009.

[19] Established by Council Decision 2002/187/JHA of 28 February 2002, with a view to reinforcing the fight against serious crime, OJ L 63, 06.03.2002; amended by EU Council Decision 2009/426/JHA on Strengthening Eurojust of 16 December 2008, OJ L 138 of 04.06 .2009 . 